Supporting information for:

\title{
Direct electrochemical regeneration of monooxygenase subunits for biocatalytic asymmetric epoxidation
}

Frank Hollmann, Karin Hofstetter, Tilo Habicher,, Bernhard Hauer, and Andreas Schmid 


\section{Reaction conditions:}

The electroenzymatic epoxidation reactions were performed either using the setup of a divided electrochemical cell or of an undivided cell.
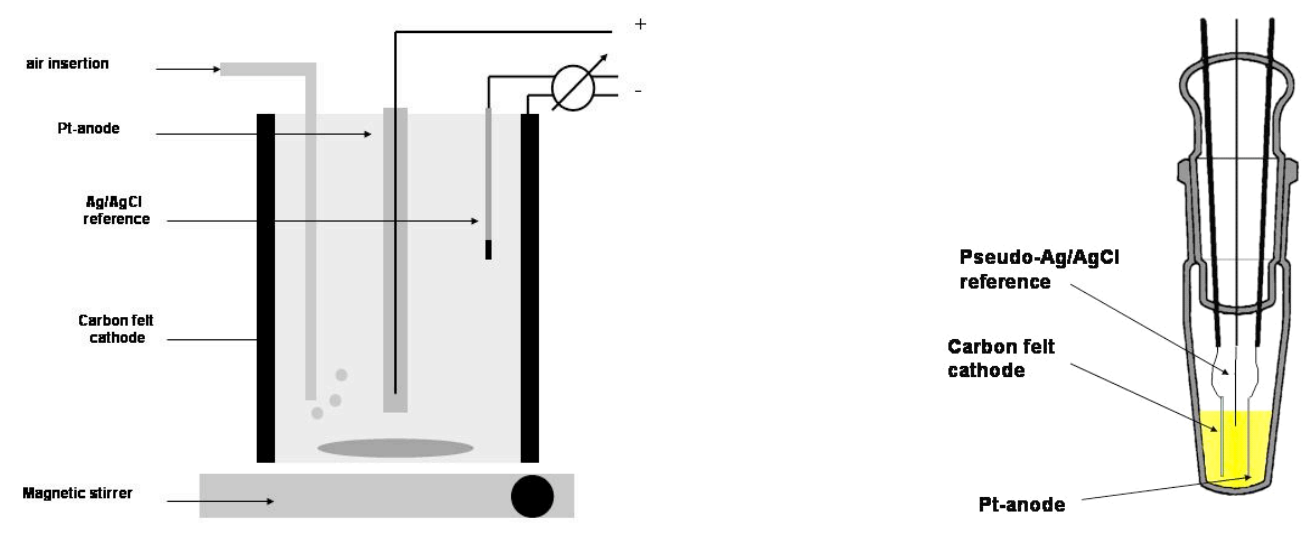

Schematic representation of the divided electrochemical cell (left) and the undivided setup (right).

Electrolyses were performed in a thermostatted stirred tank reactor (working volume: $10 \mathrm{ml}$ ). Carbon felt served as cathode (working electrode) and the potential was adjusted versus a saturated $\mathrm{Ag} / \mathrm{AgCl}_{\text {sat. }}$. reference electrode. The dimensions of the working electrode are given a macroscopic area (corresponding to an average of $27.1 \pm 2.1 \mathrm{mg} \mathrm{cm}^{-2}$ ). Conditions of either a divided or an undivided cell were chosen. For the divided cell, the Pt-wire counter electrode was placed in a dialysis membrane; otherwise a Pt-foil $(\varnothing 1 \mathrm{~cm})$ was used. After supplementing the reactor with the reaction components indicated in Table 1, a cathode potential of $-550 \mathrm{mV}$ vs. $\mathrm{Ag} / \mathrm{AgCl}_{\text {sat. }}$ was applied. In case of a divided cell, $\mathrm{O}_{2}$ was supplied by heterogeneous aeration (intake rates were estimated with a Hewlett Packard soap film flowmeter; under the conditions of an undivided cell, $\mathrm{O}_{2}$ was generated at the counter electrode by water electrolysis.

Because hydrogen peroxide was expected to accumulate throughout the electrolyses, each reaction was conducted in the presence of approximately $450 \mathrm{U} \mathrm{ml}^{-1}$ catalase (bovine origin, Boehringer Manheim)

\section{Analytical conditions}

For analysis of the reaction components, samples were withdrawn the reactor and the compounds measured by HPLC. 0.5 volumetric equivalents acetonitrile were added to denaturate and precipitate the enzymes. After 20 minutes centrifugation (labfuge, $14000 \mathrm{rpm}$, 
RT) the samples were submitted to HPLC-analysis on a Merck/Hitachi system (LaChrom series) consisting of an L-7200 autosampler, a D-7100 gradient-pump, a L-7360 column oven, and a L-7455 diode array detector. Chromatograms were recorded at $210 \mathrm{~nm}$. Product identification was done by comparison of the retention times with authentic samples.

Optical purities of the prepared epoxides were determined either via normal phase (NP) or reverse phase (RP) HPLC. For RP-HPLC, samples were prepared as described above; for NPHPLC, the sample was extracted with 0.5 volumetric equivalents of hexane. The organic phase was dried over anhydrous $\mathrm{Na}_{2} \mathrm{SO}_{4}$ and analyzed. The chromatogram from the transformation of trans- $\beta$-methyl styrene is shown (as an example):

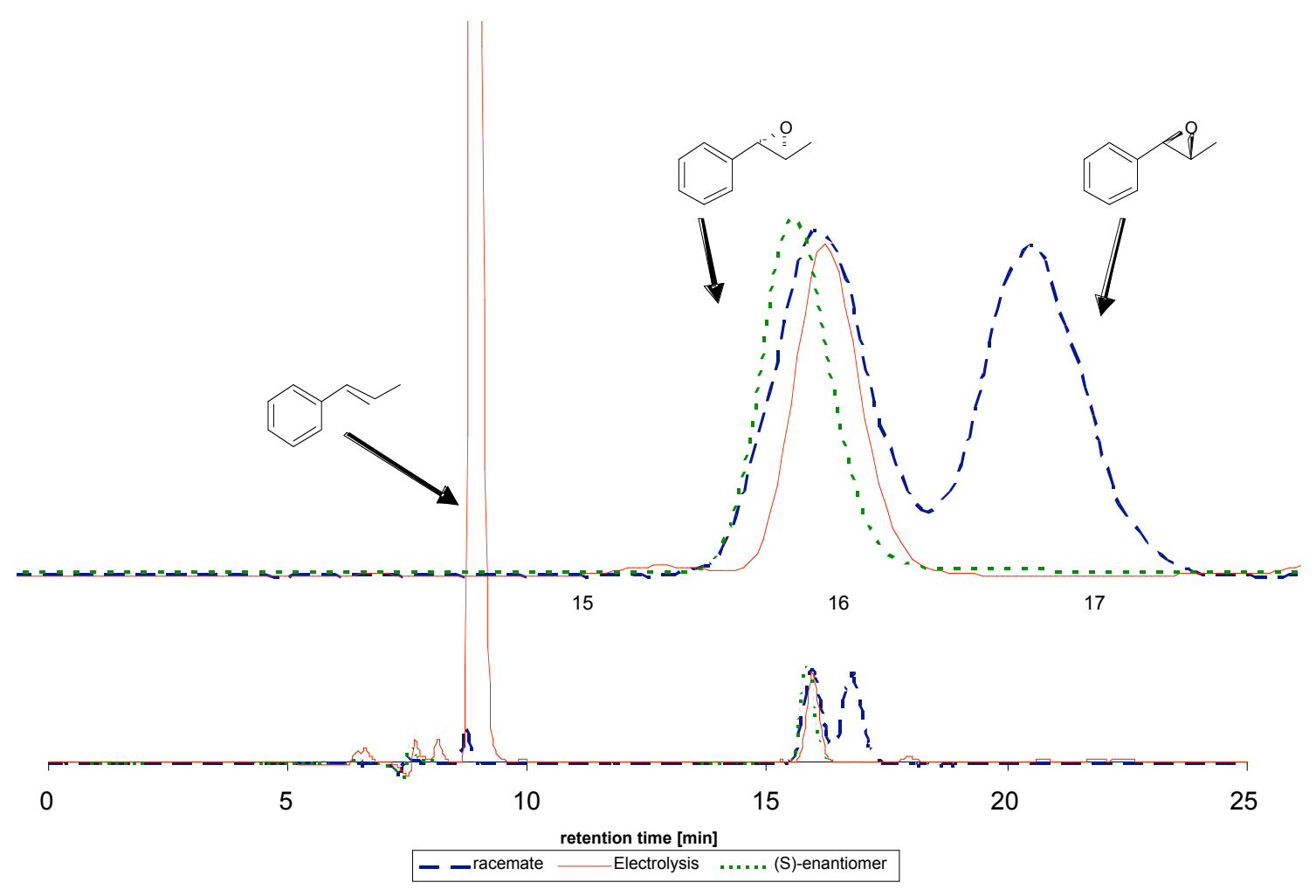




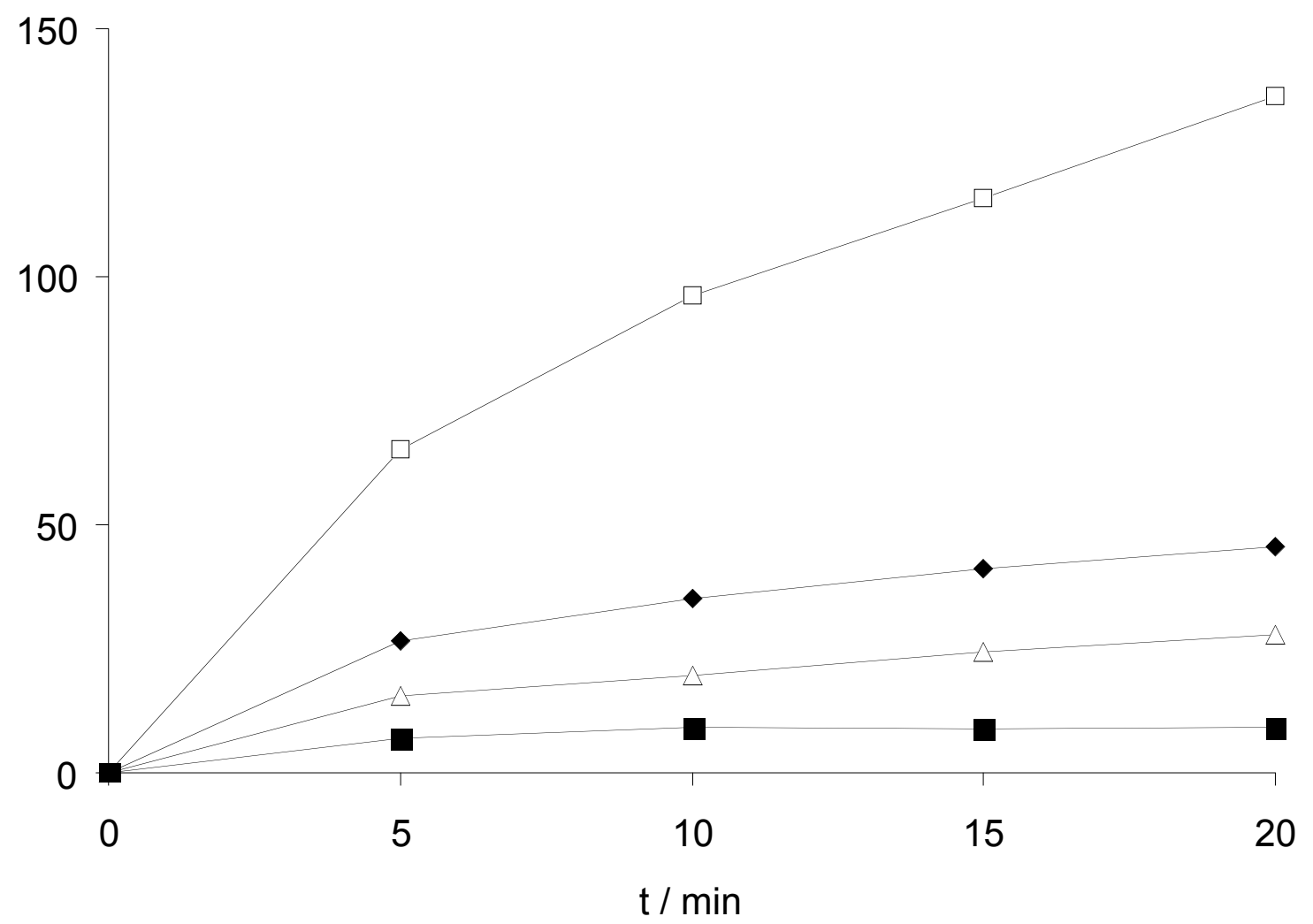

Influence of StyA-concentration on the rate of the electroenzymatic epoxidation of trans- $\beta$-methyl styrene. Reaction conditions: $12.9 \mathrm{~mL}$ potassium phosphate buffer $(50 \mathrm{mM}, \mathrm{pH} 7.5), \mathrm{T}=30^{\circ} \mathrm{C}, \mathrm{c}(\mathrm{FAD})=190 \square \mathrm{M}$, $\mathrm{c}($ catalase $)=460 \mathrm{U} \mathrm{mL}^{-1}, \mathrm{c}($ trans- $\beta$-methyl styrene $)=2 \mathrm{mM}$, cathode $: 27 \mathrm{~cm}^{2}, \mathrm{c}($ StyA $)=0.84 \square \mathrm{M}(\square), 1.64 \square \mathrm{M}$ $(\Delta), 3.35 \square \mathrm{M}(\mathrm{)}), 8.38 \square \mathrm{M}(\square)$, aeration: ca. $2 \mathrm{ml} \mathrm{min}^{-1}$. Inset: TF(StyA) calculated on initial rates. 
Influence of the cathode potential on the rate of the electroenzymatic epoxidation reaction (bubble-free aeration)

Experiments were conducted under the conditions of an undivided electrochemical cell. No external aeration was applied. As a result, cathodic and anodic currents are used for the bioelectrocatalytic reactions (200\%-electrolyses).

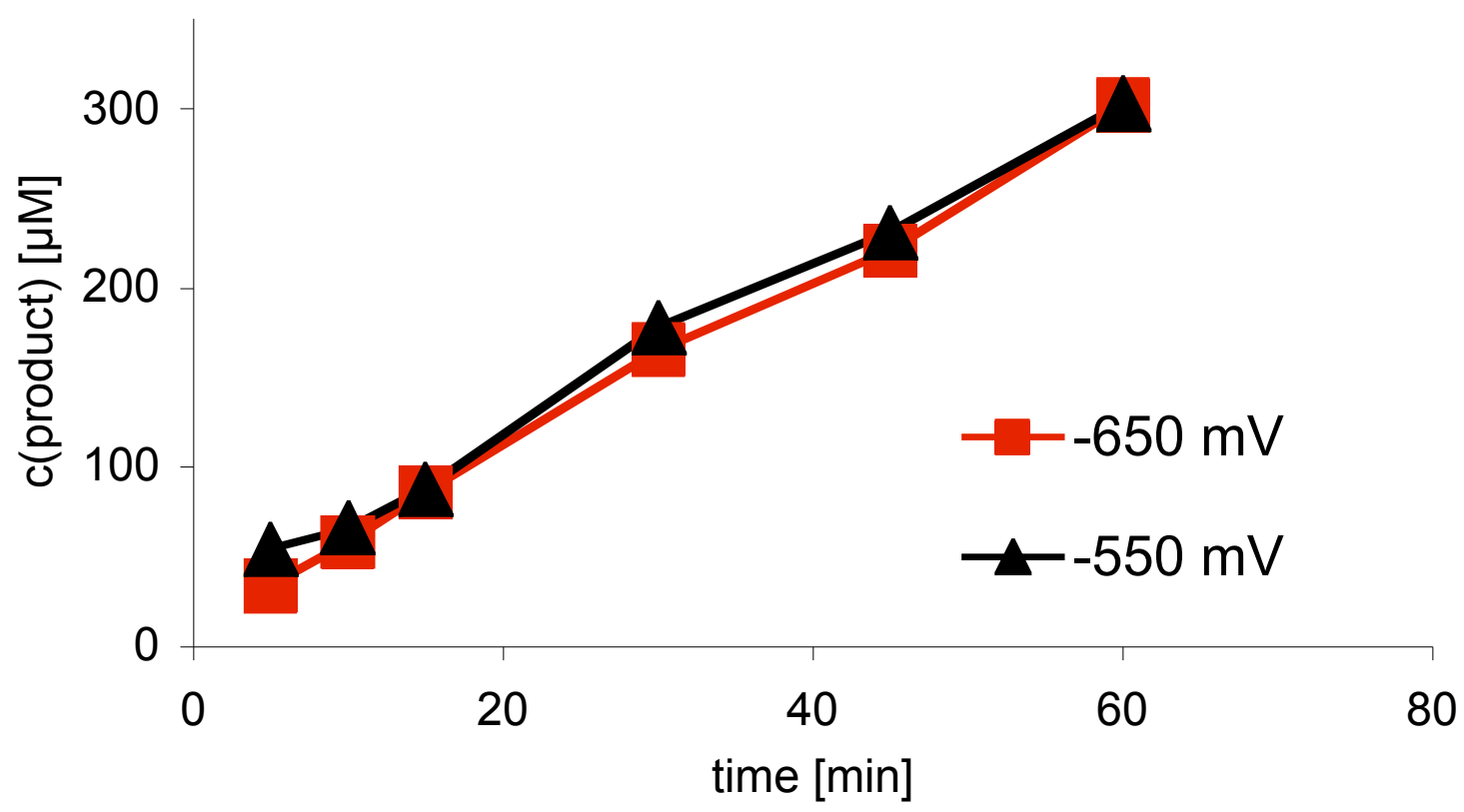

General conditions: $12 \mathrm{~mL}$ potassium phosphate buffer $(50 \mathrm{mM}, \mathrm{pH} 7.5), \mathrm{c}(\mathrm{FAD})=200 \square \mathrm{M}$, $\mathrm{c}($ Catalase $)=450 \mathrm{U} \mathrm{mL}^{-1}, \mathrm{c}($ StyA $)=6.5 \square \mathrm{M}, \mathrm{c}(\text { trans }-\beta \text {-methyl styrene })_{0}=2 \mathrm{mM}$, $\mathrm{T}=30^{\circ} \mathrm{C}$, cathode: $2.7 \mathrm{~cm}^{2}$, anode $(\mathrm{Pt}): \varnothing=1 \mathrm{~cm}$, undivided cell 


\section{Hypothetical explanation of the uncoupling reaction}

The following equations and rate constants (taken from Massey, J. Biol. Chem. 1994, 269 (36), 22459-22462) illustrate:

1. Aerobic reoxidation of $\mathrm{FADH}_{2}$ mainly occurs via pathway 1(equations 1 to 3 ) whereas pathway 2 (equations 4,5 ) is neglectable.

2. The rate-limiting step of aerobic oxidation is $\mathrm{c}\left(\mathrm{O}_{2}\right)$-independent

\section{pathway 1}

$$
\begin{aligned}
& \text { (1) } \mathrm{FADH}^{-}+\mathrm{FAD}+\mathrm{H}^{+}-2 \mathrm{k}_{2} \longrightarrow 2 \mathrm{FADH} \text {. } \\
& \text { (2) } \mathrm{FADH}+\mathrm{O}_{2} \longrightarrow \mathrm{k}_{3} \longrightarrow \mathrm{FAD}+\mathrm{O}_{2} \text {-- }^{-} \\
& \text {(3) } \mathrm{O}_{2}^{--}+\mathrm{HO}_{2}+\mathrm{H}^{+} \longrightarrow \mathrm{k}_{4} \longrightarrow \mathrm{O}_{2}+\mathrm{H}_{2} \mathrm{O}_{2}
\end{aligned}
$$

\section{pathway 2}
(4) $\mathrm{FADH}_{2}+\mathrm{O}_{2}$

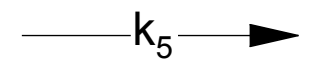
FADOOH
(5) $\mathrm{FADOOH}$

$$
\mathrm{FAD}+\mathrm{H}_{2} \mathrm{O}_{2}
$$

Rate constants values (taken from Massey, J. Biol. Chem. 1994, 269 (36), 22459-22462): $\mathrm{k}_{1}=1 \square 10^{6} \mathrm{M}^{-1} \mathrm{~s}^{-1} ; \mathrm{k}_{2}$ $=5 \square 10^{6} \mathrm{M}^{-1} \mathrm{~s}^{-1} ; \mathrm{k}_{3}=1 \square 10^{8} \mathrm{M}^{-1} \mathrm{~s}^{-1} ; \mathrm{k}_{4}=8 \square 10^{7} \mathrm{M}^{-1} \mathrm{~s}^{-1} ; \mathrm{k}_{5}=250 \mathrm{M}^{-1} \mathrm{~s}^{-1} ; \mathrm{k}_{5}=260 \mathrm{~s}^{-1}$. 